ISSN : $2302-1590$

E-ISSN: $2460-190 \mathrm{X}$

ECONOMICA

Journal of Economic and Economic Education Vol.4 No.2 (210-226)

\title{
PENGARUH GOOD CORPORATE GOVERNANCE, CSR, DAN UKURAN PERUSAHAAN TERHADAP KINERJA PERUSAHAAN
}

\author{
Melawati $^{1}$ SitiNurlaela ${ }^{2)}$ EndangMasitoh Wahyuningsih $^{3 \text { ) }}$ \\ JurusanAkuntansiFakultasEkonomi, Universitas Islam Batik Surakarta \\ Jl. H. AgusSalim No. 10 Surakarta 57147 Telp 0271-714751 \\ Email:mela.andreaz11@gmail.com
}

Submitted: 2016.01.30Reviewed:2016.07.01 Accepted: 2016.07.01

http://dx.doi.org/10.22202/economica.2016.v4.i2.380

\begin{abstract}
The aim of this study was to examine the effect of Good Corporate Governance, Corporate Social Responsibility, and the size of the company to company performance. The population in this study is a manufacturing company listed on the Stock Exchange in 2012-2014. Sampling using purposive sampling method as many as 21 companies manufacturing base and chemical industry sector in 2012-2014. The variables used are the board of directors, commissioners, Corporate Social Responsibility, and the size of the company as an independent variable, whereas the company's financial performance as the dependent variable. The analytical tool used is multiple regression analysis to examine the effect of independent variables on the dependent variable. The results showed that the size of the board of directors, the size of the commissioners and the Corporate Social Responsibility does not affect the performance of the company, only the size of the company that affect the performance of the company

Abstrak

Tujuan dari penelitian ini adalah untuk menguji pengaruh Good Corporate Governance, Corporate Social Responsibility, dan ukuran perusahaan terhadap kinerja perusahaan. Populasi dalam penelitian ini adalah perusahaan manufaktur yang listing di BEI tahun 2012-2014. Pengambilan sampel menggunakan metode purposive sampling sebanyak 21 perusahaan manufaktur sektor industri dasar dan kimia tahun 2012-2014. Variabel yang digunakan adalah dewan direksi, dewan komisaris, Corporate Social Responsibility, dan ukuran perusahaan sebagai variabel independen, sedangkan kinerja keuangan perusahaan sebagai variabel dependen. Alat analisis yang digunakan adalah analisis regresi berganda untuk menguji pengaruh variabel independen terhadap variabel dependen. Hasil penelitian menunjukkan bahwa ukuran dewan direksi, ukuran komisaris danCorporate Social Responsibilitytidak berpengaruh terhadap kinerja perusahaan, hanyaukuran perusahaan yang berpengaruh terhadap kinerja perusahaan
\end{abstract}

Keywords: GCG, CSR, Size, CFROA 


\section{PENDAHULUAN}

Indonesia menjadi salah satu negara berkembang yang mengalami pertumbuhan industri cukup signifikan. Hal itu ditandai dengan tingginya jumlah pertumbuhan perusahaan di Indonesia seperti perusahaan manufaktur maupun jasa. Perusahaan sebagai salah satu bentuk organisasi pada umumnya memiliki tujuan tertentu yang ingin dicapai dalam usaha yaitu meningkatkan nilai perusahaan dan meningkatkan kemakmuran pemilik atau para pemegang saham. Keberhasilan perusahaan dalam mencapai tujuan dapat dinilai dari kinerja perusahaan yang sekaligus dipakai sebagai salah satu dasar pengambilan keputusan baik pihak internal maupun eksternal.

Kinerja (performance) perusahaan menggambarkan tentang kondisi keuangan suatu perusahaan dengan menggunakan alatalat analisis keuangan, sehingga dapat diketahui mengenai baik buruknya keadaan keuangan perusahaan yang mencerminkan prestasi kerja dalam periode tertentu. Hal ini sangat penting agar sumber daya digunakan secara optimal dan efektif dalam menghadapi perubahan lingkungan.Laporan keuangan merupakan salah satu sumber informasi guna mendapatkan gambaran dari suatu perusahaan pada waktu tertentu (biasanya ditunjukkan dalam periode atau siklus akuntansi), yang menunjukkan kondisi keuangan yang telah dicapai suatu perusahaan dalam periode tertentu. Laporan keuangan merupakan ringkasan dari suatu proses pencatatan, yaitu merupakan suatu ringkasan dari transaksi-transaksi keuangan yang terjadi selama tahun buku yang bersangkutan berisikan neraca, laporan laba rugi, laporan perubahan posisi keuangan (yang dapat disajikan dalam berbagai cara seperti, misalnya sebagai laporan arus kas atau laporan arus dana), catatan dan laporan lain serta materi penjelasan yang merupakan bagian integral dari laporan keuangan. Aktivitas perusahaan akan tergambar didalam laporan keuangan suatu perusahaan tersebut.

Proses pencapaian maksimal dari nilai perusahaan akan muncul konflik kepentingan antara manajer dan pemegang saham (pemilik perusahaan) yang sering disebut agency problem. Tidak jarang pihak manajemen yaitu manajer perusahaan mempunyai tujuan dan kepentingan lain yang bertentangan dengan tujuan utama perusahaan dan sering mengabaikan kepentingan pemegang saham. Perbedaan kepentingan antara manajer dan pemegang saham mengakibatkan timbulnya konflik, biasanya manajer mengutamakan kepentingan pribadi, sebaliknya pemegang saham tidak menyukai kepentingan pribadi dari manajer karena apa yang dilakukan manajer tersebut akan menambah biaya bagi perusahaan sehingga menyebabkan penurunan keuntungan perusahaan dan berpengaruh terhadap harga saham sehingga menurunkan nilai perusahaan. Hal ini menegaskan bahwa dalam kegiatan menjalankan bisnis suatu perusahaan tidak hanya mengejar keuntungan melainkan harus memperhatikan tata kelola perusahaan (Corporate Governance) guna menghindari konflik yang terjadi dalam operasional perusahaan. Corporate Governance merupakan serangkaian mekanisme yang terdiri dari struktur, sistem dan proses yang digunakan oleh organ-organ dalam perusahaan untuk mengendalikan operasional perusahaan agar berjalan sesuai dengan apa yang diharapkan.Struktur merupakan rangka dasar manajemen perusahaan yang didasarkan pada pendistribusian hak-hak dan tanggung jawab di antara organ perusahaan (dewan komisaris, direksi dan RUPS/ pemegang saham) sehingga memiliki peranan yang sangat fundamental dalam implementasi suatu mekanisme CorporateGovernance.

Semenjak dimasukkannya tanggung jawab sosial dan lingkungan atau Corporate Social Responbility (CSR) sebagai suatu kewajiban dalam Amandemen RUU Perseroan Terbatas (PT) pada akhir Juni 2007, isu CSR menyedot perhatian banyak kalangan pelaku bisnis, masyarakat, pendidik, organisasi-organisasi perusahaan dan pengusaha di Indonesia. Setiap pelaku ekonomi selain berusaha untuk kepentingan pemegang saham dan mengkonsetrasikan diri pada pencapaian laba juga mempunyai tanggung jawab sosial, dan hal itu perlu diungkapkan dalam laporan tahunan sebagaimana dinyatakan oleh Pernyataan 
Standar Akuntansi Keuangan (PSAK) No.1 (Revisi 2009) paragraf kedua belas. Dewasa ini konsep CSR berkaitan erat dengan keberlangsungan atau sustainability perusahaan. Corporate Social Responsibility secara konseptual merupakan kepedulian perusahaan yang didasari triple bottom lines, yaitu profit (mencari laba), people (menyejahterakan orang), dan planet (menjamin kelangsungan planet). CSR merupakan suatu bentuk kesungguhan perusahaan untuk menyisihkan sebagian kekayaan perusahaan guna mengurangi dampak negatif yang mungkin terjadi akibat dari kegiatan usaha perusahaan dan berupaya memaksimalkan dampak positif dari operasi perusahaan terhadap semua pihak yang berkepentingan dalam ekonomi, sosial dan lingkungan. Pada prinsipnya CSR merupakan suatu komitmen berkelanjutan dari perusahaan untuk bertanggung jawab secara ekonomi, sosial, dan lingkungan atau ekologis kepada masyarakat, lingkungan, serta para pemangku kepentingan (stakeholder).

Penelitian ini mengacu pada penelitian Iqbal Bukhori (2012) yang dahulu meneliti tentang apakah GCG dan ukuran perusahaan berpengaruh positif terhadap kinerja keuangan perusahaan dengan menggunakan CFROA sebagai pengukuran kinerja keuangan, sehingga penelitian ini bertujuan untuk menguji kembali apakah GCG dan ukuran perusahaan berpengaruh positif terhadap kinerja keuangan perusahaan dengan penambahan variabel independen yaitu Corporate Social Responsibility (CSR).

\section{TinjauanPustakadanPengembanganHipote sis}

Teori keagenan merupakan hal dasar yang digunakan untuk memahami konsep Corporate Governance. Teori keagenan ini dikembangkan oleh Michael Johnson seorang Profesor dari Harvard yang memandang bahwa manjemen perusahaan (agents) akan bertindak dengan penuh kesadaran bagi kepentingannya sendiri, bukan sebagai pihak yang bijaksana serta adil terhadap pemegang saham. Teori agen dipandang lebih luas karena teori ini dianggap lebih mencerminkan kenyataan yang ada.Teori agensi ini muncul ketika ada sebuah hubungan kerja antara satu orang atau lebih (prinsipal) memberi wewenang dan bekerja sama dengan orang lain (agen) untuk menerima wewenang dan menjalankan perusahaannya. Manajer (agen) mempunyai kewajiban untuk melaporakan dan memberi informasi kepada pemilik (prinsipal), dikarenakan seorang manajer (agen) lebih mengetahui keadaan perusahaan dibanding pemilik perusahaan (prinsipal). Namun terkadang manajer tidak melaporkan keadaan perusahaan sesuai dengan keadaaan perusahaan yang sebenarnya.Teori agensi pada penelitian ini menjelaskan bahwa adanya konflik yang akan timbul antara dewan direksi dan dewan komisaris yang telah listing di BEI. Konflik tersebut terjadi ketika semakin besar jumlah dewan direksi juga akan meningkatkan permasalahan dalam hal komunikasi dan koordinasi. Semakin meningkatnya jumlah dewan direksi juga membuat pengawasan yang dilakukan akan semakin sulit, sehingga menimbulkan permasalahan agensi yang muncul dari pemisahan antara manajemen dan control.

Struktur Corporate Governance dapat dibagi menjadi dua bagian, yaitu struktur pengendalian internal dan struktur pengendalian eksternal. Struktur pengendalian eksternal terdiri dari pihak-pihak berkepentingan yang berasal dari luar perusahaan seperti pasar modal, pasar uang, regulator dan profesi lainnya (paralegal, auditor dan lain sebagainya). Penelitian ini berfokus pada struktur pengendalian internal perusahaan yang terdiri dari dewan komisaris dan dewan direksi.

Dewan komisaris merupakan salah satu fungsi kontrol yang terdapat dalam suatu perusahaan. Fungsi kontrol yang dilakukan oleh Dewan komisaris merupakan salah satu bentuk praktis dari teori agensi. Di dalam suatu perusahaan, Dewan komisaris mewakili mekanisme internal utama untuk melaksanakan fungsi pengawasan dari principal dan mengontrol perilaku oportunis manajemen. Dewan komisaris menjembatani kepentingan principal dan manajer di dalam perusahaan.

Dewan direksi merupakan pihak dalam suatu entitas perusahaan yang bertugas 
melakukan melaksanakan operasi dan kepengurusan perusahaan. Anggota dewan direksi diangkat oleh Rapat Umum Pemegang Saham (RUPS). Dewan direksi bertanggung jawab penuh atas segala bentuk operasional dan kepengurusan perusahaan dalam rangka melaksanakan kepentingan-kepentingan dalam pencapaian tujuan perusahaan. Dewan direksi juga bertanggung jawab terhadap urusan perusahaan dengan pihak-pihak eksternal seperti pemasok, konsumen, regulator dan pihak legal. Dengan peran yang begitu besar dalam pengelolaan perusahaan ini, direksi pada dasarnya memiliki hak pengendalian yang signifikan dalam pengelolaan sumber daya perusahaan dan dana dari investor.

Pengungkapan tanggung jawab sosial perusahaan yang sering juga disebut sebagai social disclosure, corporate social reporting, social accounting, atau corporate social responsibility merupakan proses pengkomunikasian dampak sosial dan lingkungan dari kegiatan ekonomi organisasi terhadap kelompok khusus yang berkepentingan dan terhadap masyarakat secara keseluruhan (Sembiring, 2005).Pengungkapan sosial yang dilakukan oleh perusahaan umumnya bersifat voluntary (sukarela), unaudited (belum diaudit), dan unregulated (tidak dipengaruhi oleh peraturan tertentu). Oleh karena itu, perusahaan memiliki kebebasan untuk mengungkapkan informasi yang tidak diharuskan oleh badan penyelenggara pasar modal. Keragaman dalam pengungkapan disebabkan oleh perusahaan yang dikelola oleh manajer yang memiliki pandangan filosofi manajerial yang berbeda dan keluasan yang berkaitan dengan pengungkapan informasi kepada masyarakat. Secara implisit pengungkapan informasi lingkungan tercermin dalam Standar Akuntansi Keuangan yang dikeluarkan oleh Dewan Standar Akuntansi Keuangan Ikatan Akuntan Publik Indonesia, yang tertulis dalam Pernyataan Standar Akuntansi Keuangan (PSAK) no. 1 (revisi 2009) paragraf dua belas.

Ukuran perusahaan merupakan salah satu variabel penting dalam pengelolaan perusahaan. Ukuran perusahaan mencerminkan seberapa besar asset total yang dimiliki perusahaan. Total asset yang dimiliki perusahaan menggambarkan permodalan, serta hak dan kewajiban yang dimilikinya. Semakin besar ukuran perusahaan, dapat dipastikan semakin besar juga dana yang dikelola dan semakin kompleks pula pengelolaannya. Sehingga ukuran perusahaan akan berpengaruh terhadap akses perusahaan untuk memperoleh sumber pendanaan. Perusahaan besar cenderung mendapat perhatian lebih dari masyarakat luas. Dengan demikian, biasanya perusahaan besar memiliki kecenderungan untuk selalu menjaga stabilitas dan kondisi perusahaan. Untuk menjaga stabilitas dan kondisi ini, perusahaan tentu saja akan berusaha mempertahankan dan terus meningkatkan kinerjanya.

\section{Hubungan Dewan Direksi dan Kinerja Perusahaan}

Dewan direksi memiliki peranan yang sangat vital dalam suatu perusahaan. Dengan adanya pemisahan peran dengan dewan komisaris, dewan direksi memiliki kuasa yang besar dalam mengelola segala sumber daya yang ada dalam perusahaan. Dewan direksi memiliki tugas untuk menentukan arah kebijakan dan strategi sumber daya yang dimiliki oleh perusahaan, baik untuk jangka pendek maupun jangka panjang.

Undang-Undang Perseroan Terbatas, disebutkan bahwa dewan direksi memiliki hak untuk mewakili perusahaan dalam urusan di luar maupun di dalam perusahaan. Jumlah dewan direksi secara logis akan sangat berpengaruh terhadap kecepatan pengambilan keputusan perusahaan. Karena tentu saja dengan adanya sejumlah dewan direksi, perlu dilakukan kordinasi yang baik antar anggota dewan komisaris yang ada.Dari uraian diatas, jelas bahwa ukuran dewan direksi merupakan salah satu mekanisme Corporate Governance yang sangat penting dalam menentukan kinerja perusahaan. Namun, dengan adanya perbedaan temuan para peneliti dalam penelitian sebelumnya, maka bukti yang diperlukan masih diperdebatkan.

H1 : Ukuran Dewan Direksi berpengaruh terhadap kinerja perusahaan 


\section{Hubungan Dewan Komisaris dan Kinerja Perusahaan}

Dewan komisaris bertugas melakukan pengawasan dan memberikan masukan kepada dewan direksi yang ada di perusahaan. Dewan komisaris tidak memiliki otoritas langsung terhadap perusahaan. Fungsi utama dari dewan komisaris adalah mengawasi kelengkapan dan kualitas informasi laporan atas kinerja dewan direksi. Posisi dewan komisaris sangat penting dalam menjembatani kepentingan principal dalam sebuah perusahaan.Semakin banyaknya anggota dewan komisaris, pengawasan terhadap dewan direksi jauh lebih baik, masukan atau opsi yang akan didapat direksi akan jauh lebih banyak. Untuk itu masih diperlukan penelitian yang dapat membuktikan pengaruh ukuran dewan komisaris ini terhadap kinerja perusahaan di Indonesia.

H2 : Ukuran Dewan Komisaris Berpengaruh terhadap Kinerja Keuangan

\section{Hubungan Corporate Social Responsibility dan Kinerja Perusahaan}

Pengungkapan CSR dilakukan oleh perusahaan akan semakin memperluas pengungkapan dalam laporan tahunan yang menjadi salah satu pedoman bagi investor dalam pengambilan keputusan untuk berinvestasi. Corporate Social Responsibility (CSR) merupakan suatu bentuk kesungguhan perusahaan untuk menyisihkan sebagian harta kekayaan perusahaan guna mengurangi dampak negatif yang mungkin terjadi dan berupaya memaksimalkan dampak positif dari operasi perusahaan terhadap semua pihak yang berkepentingan dalam kegiatan ekonomi, sosial dan lingkungan.Semakin luasnya informasi yang diterima investor akan meningkatkan tingkat kepercayaan investor terhadap perusahaan. Dengan tingkat kepercayaan yang tinggi tentunya investor akan memberikan respon yang positif terhadap perusahaan berupa pergerakan harga saham yang cenderung naik

\section{H3 : CorporateSocialResponsibility}

Berpengaruh terhadap

KinerjaPerusahaan
Hubungan ukuran perusahaan dan Kinerja Perusahaan

Ukuran perusahaan merupakan hal yang penting dalam proses pelaporan keuangan. Ukuran perusahaan dalam penelitian ini diukur dengan melihat seberapa besar asset yang dimiliki oleh sebuah perusahaan. Aset yang dimiliki perusahaan ini menggambarkan hak dan kewajiban serta permodalan perusahaan. Ukuran perusahaan akan berpengaruh terhadap perkembangan perusahaan.

H4 : Ukuran perusahaan berpengaruh terhadap kinerja perusahaan

\section{METODE PENELITIAN}

\section{Populasi dan Sampel}

Jenis penelitian ini adalah penelitian kuantitatif, yaitu penelitian yang menekankan analisisnya pada data numerikal (angka), mulai dari pengumpulan data, penafsiran terhadap data tersebut, serta penampilan dari hasilnya yang diolah dengan metoda statistik.Sumber data yang digunakan dalam penelitian ini adalah data sekunder. Data yang dibutuhkan terdapat dalam laporan keuangan auditan dan annual report tahun 2012-2014 perusahaan manufaktur dari Bursa Efek Indonesia(www.idx.co.id).

Populasi dalampenelitian ini adalah seluruh perusahaan manufaktur yang terdaftar dalam Bursa Efek Indonesia/ IndonesiaStocksExchange, selama periode 2012-2014. Sampel dalam penelitian ini adalah perusahaan manufaktur yang listing di BEI. Metode pengambilan sampel dalam penelitian ini menggunakan metode purposivesampling.

\section{Variabel Penelitian \\ Variabel dependen}

Penelitian ini menggunakan variabel dependen kinerja perusahaan. Secara umum, dalam hal ini hasil kinerja perusahaan dapat dilihat pada kinerja keuangan perusahaan. Terdapat beberapa pendekatan yang digunakan untuk menilai kinerja keuangan perusahaan, salah satunya pendekatan laporan keuangan yang menggunakan angka-angka akuntansi. Untuk mengukur kinerja keuangan perusahaan, peneliti menggunakan 
pengukuran yang telah dilakukan oleh Bukhori (2012) Cash Flow Return On Asset (CFROA). CFROA dihitung dari laba sebelum bunga dan pajak ditambah depresiasi dibagi dengan total aktiva.

\section{VariabelIndependen}

Variabel indpenden yang digunakan dalam penelitian ini terdiri dari dewan direksi, dewan komisaris, CorporateSocialResponsibility, dan ukuran perusahaan. Ukuran dewan direksi diukur dengan menggunakan jumlah anggota dewan direksi dalam suatu perusahaan. Sementara ukuran dewan komisaris diperoleh dari jumlah total anggota dewan komisaris, baik yang berasal internal perusahaan maupun dari eksternal perusahaan sampel. Ukuran dewan komisaris diukur dengan menggunakan indikator jumlah anggota dewan komisaris suatu perusahaan. Pengukuran pengungkapan lingkungan perusahaan dapat diperoleh melalui pengungkapan CSR dalam annual report maupun melalui sustainability report.. CSRI ditentukan menggunakan 7 tema yang terdiri dari lingkungan, energi, kesehatan dan keselamatan tenaga kerja, lain-lain tentang tenaga kerja, produk, keterlibatan masyarakat, dan umum. Keseluruhan tema tersebut berjumlah 78 item (Sembiring, 2005).Apabila item $y$ diungkapkan maka diberikan nilai 1, jika item $y$ tidak diungkapkan maka diberikan nilai 0 pada check list. Hasil pengungkapan item yang diperoleh dari setiap perusahaan dihitung indeksnya dengan proksi CSRI.

$$
\operatorname{CSRIj}=\frac{\sum \mathrm{Xyi}}{\mathrm{ni}}
$$

CSRIj : Indeks luas pengungkapan tanggung jawab sosial dan lingkungan perusahaan i

$\sum X y i$ : $\quad$ nilai $1=$ jika item y diungkapkan; $0=$ jika item y tidak diungkapkan

$\mathrm{n}_{\mathrm{i}}$ : jumlah item untuk perusahaan $\mathrm{I}$, $\mathrm{ni} \leq 78$

Ukuran perusahaan dimaksud disini adalah seberapa besar asset yang dimiliki oleh perusahaan tersebut. Ukuran perusahaan disini diukur dengan menggunakan total aset yang dimiliki perusahaan yang diperoleh dari laporan keuangan tahunan perusahaan untuk tahun 2012-2014. Metode pengukuran ini berdasarkan pengukuran yang telah dilakukan oleh Khafa (2015). SIZE = log (total aktiva).

\section{MetodeAnalisis \\ Uji Statistik Deskriptif}

Statistik deskriptif digunakan untuk mendeskripsikan atau memberikan gambaran secara ringkas variabel-variabel dalam penelitian ini melalui data sampel atau populasi sebagaimana adanya, tanpa melakukan analisis dan membuat kesimpulan yang berlaku untuk umum.

\section{Uji Asumsi Klasik \\ Uji Normalitas}

Uji normalitas bertujuan untuk menguji apakah dalam model regresi, variabel pengganggu atau residual memiliki distribusi normal.

Penelitianinimenggunakanujinormalitas Kolm ogorov-Smirnov Test. Jika nilai probabilitas (Kolmogorov-Smirnov) < taraf signifikansi, maka distribusi data dikatakan tidak normal dan Jika nilai probabilitas (KolmogorovSmirnov) > taraf signifikansi, maka distribusi data dikatakan normal.

\section{Uji Multikolinearitas}

Uji Multikolonearitas bertujuan untuk mengetahui apakah model regresi ditemukan adanya korelasi antar variabel independen (bebas). Model regresi yang baik seharusnya tidak terjadi korelasi di antara variabelvariabel independen. Menurut Ghozali (2006) cara untuk mendeteksi ada atau tidaknya multikolonearitas di dalam model regresi adalah denganmelihatnilai Tolerance dan Variance Inflation Factor (VIF). Tolerance mengukur variabel bebas yang terpilih yang tidak dapat dijelaskan oleh variabel bebas lainnya. Jadi nilai tolerance rendah sama dengan nilai VIF tinggi (karena VIF = 1/tolerance) dan menunjukkan nilai kolinearitas yang tinggi. Nilai cutoff yang umum dipakai adalah nilai tolerance 0,10 atau sama dengan nilai VIF di atas 10.

\section{Uji Autokorelasi}


Uji autokorelasi digunakan untuk mengetahui apakah dalam model regresi linear terdapat korelasi antara kesalahan pengganggu pada periode $t$ dengan kesalahan pengganggu pada periode $\mathrm{t}-1$ (sebelumnya). Model regresi yang baik adalah regresi yang bebas dari autokorelasi.Salah satu cara untuk mendeteksi ada atau tidaknya autokorelasi yaitu dengan Uji Durbin-Watson (DWtest). Uji Durbin Watson digunakan untuk autokorelasi tingkat satu (first order autocorrelation) dan mensyaratkan adanya intercept (konstanta) dalam model regresi dan tidak ada variabel lag diantara variabel independen (Ghozali, 2006). Dasar pengambilan keputusan ada tidaknya autokorelasi dengan menggunakan tabel Durbin-Watson (Ghozali, 2009) yang terlampir.

\section{Uji Heterokedastisitas}

Uji Heteroskedastisitasbertujuan untuk mengetahui apakah dalam model regresi terjadi ketidaksamaan variance dari residual satu pengamatan kepengamatan lain.Menurut Ghozali (2006) ada beberapa cara untuk mendeteksi ada atau tidaknya heteroskedastisitas antara lain adalah dengan melakukan uji park, uji glejser, uji white dan melihat grafik scatterplot antara nilai prediksi variabel terikat (dependent) yaitu ZPRED dengan residualnya SRESID.

\section{Analisis Regresi}

Analisis yang digunakan dalam pengolahan data penelitian ini adalah analisis regresi linier berganda (multiple linear regression). Analisis regresi berganda digunakan untuk menguji pengaruh dari beberapa variabel bebas terhadap satu variabel terikat. Analisis regresi dapat memberikan jawaban mengenai besarnya pengaruh setiap variabel independen terhadap variabel dependennya.

Model pengujian dalam penelitian ini dinyatakan dalam persamaan dibawah ini:

$$
C F R O A=\forall+\exists_{1} \mathrm{DD}+\exists_{2} \mathrm{DK}_{+} \exists_{3} \mathrm{CSRI}_{+} \exists_{4} \mathrm{CZ}
$$

Keterangan:

CFROA : Kinerja Perusahaan

$\begin{array}{llll}\forall & : \text { Intercept/ konstanta } & \\ \exists_{1}, \exists_{2}, \exists_{3} & : \text { Koefisien Regresi } & \\ \text { DD } & : \text { Ukuran Dewan Direksi } & \\ \text { DK } & : \text { Ukuran Dewan Komisaris } & \\ \text { CSRI } & : \text { CSR Indeks } & & \\ \text { CZ } & : \text { Logaritma Natural Ukuran } \\ & & \text { Perusahaan } & \\ , & : \text { Error }\end{array}$

Uji Hipotesis

Uji F

Uji statistik $F$ pada dasarnya menunjukkan apakah semua variabel independen atau bebas yang dimasukkan dalam model mempunyai pengaruh secara bersama-sama terhadap variabel dependen. Uji $F$ dilakukan dengan membandingkan antara nilai F-tabel dengan F-hitung hasil run regresi yang dilakukan. Jika nilai F-tabel $<$ Fhitung maka dapat disimpulkan model dapat diterima.

\section{Uji Parsial (Uji t)}

Uji $t$ statistik pada dasarnya menunjukkan seberapa jauh pengaruh satu variabel penjelas atau independen secara individual menerangkan variansi variabel dependen (Ghozali, 2006). Penetapan untuk mengetahui hipotesis diterima atau ditolak dengan membandingkan $\mathrm{t}$ hitung dengan $\mathrm{t}$ tabel. Jika t hitung lebih kecil daripada t tabel artinya bahwa tidak ada pengaruh yang signifikan dari variabel bebas secara individual terhadap variabel dependen. Jika $t$ hitung lebih besar dari t tabel artinya ada pengaruh yang signifikan dari variabel bebas secara individual terhadap variabel independen.

\section{Uji Koefisien Determinan}

Koefisien determinan $\left(\mathrm{R}^{2}\right)$ ini digunakan untuk menggambarkan kemampuan model menjelaskan variasi yang terjadi dalam variabel dependen (Ghozali, 2006). Koefisien determinasi $\left(\mathrm{R}^{2}\right)$ dinyatakan dalam persentase. Nilai koefisien korelasi $\left(\mathrm{R}^{2}\right)$ ini berkisar antara $0<\mathrm{R}^{2}<1$. Semakin besar nilai yang dimiliki, menunjukkan bahwa semakin banyak informasi yang mampu diberikan oleh variabel-variabel independen 
untuk memprediksi variansi variabel dependen.

\section{PEMBAHASAN}

\section{DeskripsiUmum Data Penelitian}

Populasi penelitian yang digunakan dalam penelitian ini adalah seluruh perusahaan manufaktur yang tercatat di Bursa Efek Indonesia pada tahun 2012-2014 sebanyak 141 perusahaan. Akan tetapi setelah dilakukan purposivesampling, maka sampel yang layak digunakan adalah sebanyak 21 perusahaan.Ringkasan prosedur pemilihan sampel dapat dilihat pada tabel 1 (terlampir).

\section{AnalisisStatistikDeskriptif}

Hasil Perhitungan Deskriptif pengaruh Good Corporate Governance (dewan direksi dan dewan komisaris), Corporate Social Responsibility (CSR), dan ukuran perusahaan terhadap kinerja keuangan perusahaan (CFROA) untuk semua perusahaan selama periode penelitian yaitu tahun 2012-2014 di sajikan dalam tabel 3 (terlampir)

Berdasarkan hasil statistik deskriptifsepertitabel 3 (terlampir) rata-rata (mean) ukuran dewan direksi sebesar 5,5873 dengan standar deviasi 2,57554 yang berarti bahwa tingkat penyimpangan datanya kecil. Nilai maksimum dewan direksi sebesar 11,00, yang berarti bahwa nilai tertinggi yang ada dalam data sampel variabel dewan direksi adalah 11. Sementara nilai terendah (minimum) jumlah anggota dewan direksi sebesar 2,00. Variabel dewan komisaris tahun 2012-2014 menghasilkan nilai tertinggi (maksimum) sebesar 9,00. Sementara nilai terendah (minimum) jumlah total anggota dewan komisaris sebesar 2. Nilai rata-rata (mean) ukuran dewan komisaris sebesar 4,4603 dengan standar deviasi 1,73042 menunjukkan bahwa semakin menjauhi nilai rata-rata dan variasi datanya semakin besar yang berarti tingkat penyimpangan datanya kecil.Variabel Corporate Social Responsibility pada tahun 2012-2014 menghasilkan nilai tertinggi (maksimum) sebesar 0,77. Sementara nilai terendah (minimum) pengungkapan CSR sebesar 0,09. Nilai rata-rata (mean) CSR sebesar 0,3424 dengan standar deviasi 0,18949 lebih kecil dari rata-rata yang berarti tingkat penyimpangan datanya kecil.Ukuran perusahaan diukur dengan total aset yang dimiliki perusahaan. Berdasarkan hasil statistik deskriptif rata-rata (mean) ukuran perusahaan sebesar 12,2757 dengan standar deviasi 0,70995 yang berarti bahwa tingkat penyimpangan datanya kecil. Nilai maksimum ukuran perusahaan sebesar 13,54. Sementara nilai terendah (minimum) total asset yang dimiliki perusahaan sebesar 11,11. Variabel kinerja perusahaan tahun 2012-2014 menghasilkan nilai tertinggi (maksimum) sebesar 0,35. Sementara nilai terendah (minimum) sebesar 0,00 . Nilai rata-rata (mean) sebesar 0,1023 dengan standar deviasi atau simpangan baku 0.08766 lebih kecil dari rata-rata menunjukkan tingkat penyimpangan datanya kecil.

\section{Analisis Asumsi Klasik UjiNormalitas}

Berdasarkan tabel 4(terampir) dapat dilihat besarnya nilai statistik KolmogorovSmirnov adalah 0,755 dan nilai AsymptoticSignificance sebesar 0, 618. Karena signifikansi lebih besar dari 0,05 maka Ho diterima yang menunjukkan data residual terdistribusi secara normal. Jadi, dapat disimpulkan bahwa persamaan regresi pada model memenuhi asumsi normalitas.

\section{UjiMultikolinearitas}

Berdasarkan tabel 5 dapat dilihat bahwa keempat variabel independen dewan komisaris (x1), dewan direksi (x2), Corporate Social Responsibility (x3), ukuran perusahaan (x4) tidak terjadi multikolinearitas karena nilai tolerance $>0,10$ dan nilai $\mathrm{VIF}<10$ menunjukkan model regresi dapat dipercaya dan obyektif. Jadi, dapat disimpulkan bahwa tidak ada multikolinieritas antar variabel independen dalam model regresi, sehingga data yang dianalisis memenuhi asumsi multikolinearitas.

\section{UjiAutokorelasi}

Menurut tabel 6 uji autokorelasi menunjukkan nilai Durbin-Watson sebesar 2,206 . Nilai $d w$ yang berada pada daerah $d U$ $<\mathrm{dw}<4$-dU dapat disimpulkan model regresi 
terbebas dari problem autokorelasi dan layak digunakan. Nilai dL dan dU diketahui dari jumlah variabel independen yaitu empat (4) dan jumlah sampel sebanyak 63, maka didapatkan nilai $\mathrm{dL}=1,4607$ dan nilai $\mathrm{dU}=$ 1,7296. Hasil pengujian dalam penelitian ini, nilai Durbin-Watson harus berada diantara 1,7296 (dU) dan 2,2704 (4-dU), agar tidak mengalami masalah autokorelasi. Hasil analisis menunjukkan nilai Durbin-Watson untuk variabel dependen kinerja perusahaan (CFROA) telah berada diantara 1,7296 (dU) dan 2,2704 (4-dU), sehingga dapat disimpulkan model regresi terbebas dari problem autokorelasi dan layak digunakan.

\section{UjiHeteroskedastisitas}

Berdasarkan gambar 1 (terlampir) uji heteroskedastisitas memperlihatkan grafikgrafik scatterplot dari variabel dependen yaitu kinerja perusahaan (CFROA). Grafik scatterplot tersebut menunjukkan bahwa titiktitik menyebar di atas dan di bawah angka 0 pada sumbu Y, hal ini berarti bahwa model penelitian ini tidak terdapat heteroskedastisitas.

\section{AnalisisRegresi}

Atas dasar uji statistik regresi yang telah dilakukan dapat diperoleh persamaan matematis dari penelitian ini sebagai berikut:

$$
\begin{gathered}
\mathrm{Y}=-0,518+0,002 D D-0,002 D K+ \\
0,076 C S R I+0,048 C Z+\mathrm{e}
\end{gathered}
$$

Nilai-nilai yang masuk dalam persamaan regresi linier berganda didapat dari output SPSS versi 17 menunjukkan bahwa:

1. Nilai konstanta $(\forall)$ adalah $-0,518$. Artinya, jika dewan direksi, dewan komisaris,

CorporateSocialResponsibility, dan ukuran perusahaan bernilai 0 , maka kinerja perusahaan bernilai negative (0,518).

2. Nilai koefisien regresi variabel dewan direksi ( $\exists 1$ ) bernilai positif, yaitu 0,002 . Artinya setiap peningkatan jumlah dewan direksi sebesar 1 satuan akan meningkatkan kinerja perusahaan sebesar 0,002 dengan asumsi variabel lain bernilai tetap.
3. Nilai koefisien regresi variabel dewan komisaris $(\exists 2)$ bernilai negatif, yaitu 0,002 . Artinya setiap penurunan jumlah dewan komisaris sebesar 1 satuan akan menurunkan kinerja perusahaan sebesar 0,002 dengan asumsi variabel lain bernilai tetap.

4. Nilai koefisien regresi variabel CorporateSocialResponsibility

bernilai positif 0,076. Artinya setiap peningkatan jumlah pengungkapan tanggung jawab sosial sebesar 1 satuan akan meningkatkan kinerja perusahaan sebesar 0,076 dengan asumsi variabel lain bernilai tetap.

5. Nilai koefisien regresi variabel ukuranperusahaan $(\exists 4)$ bernilai positif 0,048 . Artinya setiap peningkatan total asset perusahaan sebesar 1 satuan akan meningkatkan kinerja perusahaan sebesar 0,048 dengan asumsi variabel lain bernilai tetap.

\section{HasilUjiHipotesis Uji F}

Berdasarkan hasil output SPSS versi 17 tabelanova (terlampir) didapatF hitung $>\mathrm{F}$ tabel $(5,093>2,531)$ dan signifikansi $(0,001)$ $<0,05$, maka Ho ditolak. Jadi dapat disimpulkan bahwa dewan direksi, dewan komisaris, CorporateSocialResponsibility, dan ukuran perusahaan secara bersama-sama berpengaruh terhadap kinerja perusahaan, artinya ada pengaruh yang signifikan dari dewan direksi, dewan komisaris, CorporateSocialResponsibility, dan ukuran perusahaan terhadap kinerja perusahaan. Hal ini menunjukkan bahwa variabel independen sudah tepat untuk mengukur variabel dependennya sehingga model regresi sudah fit

\section{UjiParsial (Uji t)}

Berdasarkan tabel 5(terlampir) diperoleh nilai t hitung untuk variabel dewan direksi sebesar 0,396. Nilai t tabel dapat dilihat pada tabel statistik signifikansi $0,05 / 2$ $=0,025$ dengan derajat kebebasan $\mathrm{df}=\mathrm{n}-\mathrm{k}-1$ atau 63-4-1 = 58 ( $\mathrm{n}$ adalah jumlah data dan $\mathrm{k}$ adalah jumlah variabel independen). Hasil yang diperoleh untuk $t$ tabel sebesar 2,002. 
Hasil pengujian output SPSS nilai $-\mathrm{t}$ tabel $\leq \mathrm{t}$ hitung $\leq \mathrm{t}$ tabel $(-2,002 \leq 0,396 \leq 2,002)$ dan signifikansi 0,694 >0,05 maka hasil hipotesis pertama Hoditerima. Hal ini dapat disimpulkan bahwa secara parsial ukuran dewan direksi tidak berpengaruh terhadap kinerja perusahaan (CFROA).

Nilai t hitung untuk variabel dewan komisaris sebesar -0,253. Hasil pengujian output SPSS nilai -tabel $\leq \mathrm{t}$ hitung $\leq \mathrm{t}$ tabel $(-$ $2,002 \leq-0,253 \leq 2,002)$ dan signifikansi 0,801 > 0,05 maka hasil hipotesis kedua Ho diterima. Hal ini dapat disimpulkan bahwa secara parsial ukuran dewan komisaris tidak berpengaruh terhadap kinerja perusahaan (CFROA).

Nilai $\mathrm{t}$ hitung Variabel CorporateSocialResponsibilitypadatabeldiatas sebesar 1,013. Hasil pengujian output SPSS nilai - tabel $\leq \mathrm{t}$ hitung $\leq \mathrm{t}$ tabel $(-2,002 \leq 1,013$ $\leq 2,002)$ dan signifikansi $0,315>0,05$ maka hasil hipotesis ketiga Ho diterima. Hal ini dapat disimpulkan bahwa secara parsial CorporateSocialResponsibility tidak berpengaruh terhadap kinerja perusahaan (CFROA).

Nilai $\mathrm{t}$ hitung untuk variabel ukuran perusahaan sebesar 3,113. Hasil pengujian output SPSS nilai $\mathrm{t}$ hitung $>\mathrm{t}$ tabel $(3,113>$ 2,002) dan signifikansi $0,003<0,05$ maka hasil hipotesis keempat Ho ditolak. Hal ini dapat disimpulkan bahwa secara parsial ukuran perusahaan berpengaruh terhadap kinerja perusahaan (CFROA).

\section{HasilKoefisienDeterminan}

Nilai koefisien determinasi (AdjustedR $^{2}$ ) sebesar 0,209 yang berarti variabilitas variabel dependen yang dapat dijelaskan oleh variabelitas variabel independen sebesar 20,9\%. Hal ini berarti $20,9 \%$ variasi kinerja perusahaan yang bisa dijelaskan oleh variasi dari keempat variabel independen yaitu variabel dewan direksi (x1), dewan komisaris

$(\mathrm{x} 2)$, CorporateSocialResponsibility (x3), ukuran perusahaan $(\mathrm{x} 4)$ sedangkan sisanya sebesar $79,1 \%$ dijelaskan oleh variabel lainnya yang tidak dimasukkan dalam model regresi.

\section{Pengaruh Dewan Direksi terhadap Kinerja Perusahaan}

Berdasarkan output SPSS, hasil pengujian hipotesis secara parsial menunjukkan bahwa variabel dewan direksi tidak berpengaruh terhadap kinerja perusahaan. Artinya dengan adanya jumlah dewan direksi yang besar dapat menyebabkan kerugian yang berkaitan dengan meningkatnya permasalahan dalam hal komunikasi dan koordinasi. Selain itu, permasalahan yang timbul adalah pengambilan keputusan. Dewan direksi yang merupakan bagian internal manajemen memiliki peranan yang sangat vital dalam suatu perusahaan. Dengan adanya pemisahan peran dengan dewan komisaris, dewan direksi memiliki kuasa yang besar dalam mengelola segala sumber daya yang ada dalam perusahaan. Dewan direksi memiliki tugas untuk menentukan arah kebijakan dan strategi sumber daya yang dimiliki oleh perusahaan, baik untuk jangka pendek maupun jangka panjang. Penelitian ini sejalan dengan penelitian Bukhori (2012) yang menyimpulkan jumlah dewan yang besar menguntungkan perusahaan dari sudut pandang pengelolaan sumber daya. Akan tetapi, semakin besar jumlah dewan direksi juga akan meningkatkan permasalahan dalam hal komunikasi dan koordinasi. Semakin meningkatnya jumlah dewan direksi juga membuat pengawasan yang dilakukan akan semakin sulit, sehingga menimbulkan permasalahan agensi yang muncul dari pemisahan antara manajemen dan control. Penelitian ini juga mendukung penelitianPeruno (2015) yang menyimpulkan bahwa jumlah dewan direksi juga akan mempengaruhi kemajuan perusahaan. Namun, penelitian ini tidak sejalan dengan Sukandar (2014) dan Yudha (2015) yang menyatakan bahwa dewan direksi memiliki pengaruh yang signifikan terhadap kinerja keuangan perusahaan.

\section{Pengaruh Dewan Komisaris Terhadap Kinerja Perusahaan}

Berdasarkan output SPSS, hasil pengujian hipotesis secara parsial 
menunjukkan bahwa variabel ukuran dewan komisaris tidak berpengaruh terhadap kinerja perusahaan. Artinya dewan komisaris sebagai mekanisme penggendalian internal tertinggi yang bertanggung jawab secara kolektif untuk melakukan pengawasan dan memberi masukan kepada direksi dalam mengelola sumber daya perusahaan belum mampu menegakkan GCG di dalam perusahaan. Semakin banyak personil yang menjadi dewan komisaris dapat berakibat pada makin buruk kinerja yang dimiliki perusahaan. Hasil penelitian ini sejalan dengan penelitian Bukhori (2012) dan Sukandar (2014) yang menyimpulkan dewan komisaris tidak berpengaruh terhadap kinerja perusahaan. Hasil ini juga mendukung penelitian Muntiah (2014) yang menyebutkan bahwa semakin banyaknya anggota dewan komisaris maka badan ini akan mengalami kesulitan dalam menjalankan perannya, diantaranya kesulitan dalam komunikasi dan koordinasi antar anggota dewan komisaris. Namun, penelitian ini bertolak belakang dengan hasil penelitian Hardikasari (2011) yaitu dewan komisaris berpengaruh positif terhadap kinerja perusahaan dan penelitian Mulyadi (2014) yang menyimpulkan bahwa ukuran dewan komisaris berpengaruh negatif terhadap kinerja perusahaan. Semakin bertambah jumlah dewan komisaris akan mengurangi kinerja perusahaan.

\section{Pengaruh CorporateSocialResponsibility Terhadap Kinerja Perusahaan}

Hasil pengujian hipotesis secara parsial menunjukkan bahwa variabel CorporateSocialResponsibility tidak berpengaruh terhadap kinerja perusahaan. Artinya, tanggung jawab sosial (CSR) yang dilakukan oleh perusahaan yang diungkapkan dalam laporan tahunan perusahaan tidak mendapat respon dari calon investor karena sudah ada regulasi yang menjamin untuk setiap perusahaan melakukan dan mengungkapkan CSR. Perseroan yang tidak melaksanakan CSR akan dikenakan sanksi administratif berupa peringatan tertulis, pembatasan kegiatan usaha, pembekuan kegiatan usaha dan/atau fasilitas penanaman modal atau pencabutan kegiatan usaha dan/atau fasilitas penanaman modal. Penelitian ini sejalan dengan penelitian Hana (2013) yang menyatakan bahwa aktivitas CSR yang dilakukan oleh perusahaan tidak terbukti memiliki dampak produktif yang signifikan terhadap kinerja keuangan perusahaan. Hasil penelitian ini mengindikasikan bahwa perilaku etis perusahaan berupa tanggung jawab sosial terhadap lingkungan sekitarnya tidak mendapat respon oleh para investor. Terdapat indikasi bahwa para investor tidak perlu melihat pengungkapan CSR yang telah dilakukan oleh perusahaan, karena terdapat jaminan yang tertera pada UU Perseroan Terbatas No. 40 Tahun 2007, bahwa perusahaan pasti melaksanakan CSR dan pengungkapannya, dan apabila perusahaan tidak melaksanakan CSR, maka perusahaan akan terkena sanksi sesuai dengan ketentuan peraturan perundang-undangan. Namun penelitian ini tidak sejalan dengan penelitian Khafa (2015) dan Setiyowati (2015) yang menyimpulkan bahwa CSR berpengaruh positif terhadap kinerja keuangan perusahaan. Setiyowati (2015) menyatakan semakin banyak item pengungkapan corporate social responsibility, semakin baik kinerja keuangan. Dalam jangka panjang, akan berdampak pada semakin tinggi tingkat kesejahteran para investor, karyawan, dan stakeholder lainnya

\section{Pengaruh Ukuran Perusahaan Terhadap Kinerja Perusahaan}

Berdasarkan ujihipotesis yang telahdilakukann secara parsial menunjukkan bahwa variabel ukuran perusahaan berpengaruh terhadap kinerja perusahaan. Hal ini menunjukkan bahwa ukuran perusahaan dengan jumlah asset yang semakin besar maka semakin besar modal yang ditanam dan semakin besar juga perputaran dana dalam perusahaan yang dikelola sehingga dapat meningkatkan kinerja keuangan perusahaan, namun semakin kompleks pula pengelolaanya. Hasil penelitian ini mendukung penelitian yang dilakukan oleh Khafa (2015) dan Siagian (2013) yang mengatakan bahwa perusahaan yang beraset besar memiliki akses untuk meningkatkan kinerja perusahaan. Perusahaan yang besar 
akan mendapat perhatian lebih dari masyarakat sehingga harus bersikap hati-hati dalam melakukan pelaporan keuangannya. Sementara penelitian Rifan (2015) mengatakan bahwa ukuran perusahaan memiliki hubungan yang negatif terhadap ROA dan ROE, yang berarti ukuran perusahaan yang semakin besar akan berdampak pada penurunan nilai ROA dan ROE. Hasil penelitian ini bertolak belakang dengan penelitian Bukhori (2012) yang mengatakan ukuran perusahaan yang besar belum tentu menghasilkan kinerja keuangan yang lebih baik. Semakin besar aset yang dimiliki perusahaan, semakin kompleks pula masalah agensi yang dihadapi. Hasil penelitian ini juga tidak sejalan dengan penelitian Sukandar (2014) yang menyebutkan bahwa ukuran perusahaan tidak memiliki pengaruh yang signifikan terhadap CFROA atau kinerja keuangan perusahaan.

\section{PENUTUP}

Penelitian ini bertujuan untuk
mengetahui

\section{GoodCorporateGovernance,}

CorporateSocialResponsibility, dan ukuran perusahaan terhadap kinerja perusahaan. Populasi dalam penelitian ini adalah perusahaan manufaktur yang listing di BEI tahun 2012-2014. Pengambilan sampel menggunakan metode purposivesampling sebanyak 21 perusahaan manufaktur sektor industri dasar dan kimia tahun 2012-2014. Variabel yang digunakan adalah dewan direksi, dewan komisaris, Corporate Social Responsibility, dan ukuran perusahaan sebagai variabel independen, sedangkan kinerja keuangan perusahaan sebagai variabel dependen. Alat analisis yang digunakan adalah analisis regresi berganda untuk menguji pengaruh variabel independen terhadap variabel dependen. Hasil penelitian menunjukkan bahwa ukuran dewan direksi tidak berpengaruh terhadap kinerja perusahaan. Artinya dengan adanya jumlah dewan direksi yang besar dapat menyebabkan kerugian yang berkaitan dengan meningkatnya permasalahan dalam hal komunikasi dan koordinasi.Dewankomisaristidakberpengaruht
erhadapkinerjaperusahaan.Artinya, dewan komisaris sebagai mekanisme penggendalian internal tertinggi yang bertanggung jawab secara kolektif untuk melakukan pengawasan dan memberi masukan kepada direksi dalam mengelola sumber daya perusahaan belum mampu menegakkan GCG di dalam perusahaan.CorporateSocialResponsibility tidak berpengaruh terhadap kinerja perusahaan. Tanggung jawab sosial (CSR) yang dilakukan oleh perusahaan yang diungkapkan dalam laporan tahunan perusahaan tidak mendapat respon dari calon investor karena sudah ada regulasi yang menjamin untuk setiap perusahaan melakukan dan mengungkapkan CSR. Perseroan yang tidak melaksanakan CSR akan dikenakan sanksi administratif berupa peringatan tertulis, pembatasan kegiatan usaha, pembekuan kegiatan usaha dan/atau fasilitas penanaman modal atau pencabutan kegiatan usaha dan/atau fasilitas penanaman modal. Ukuran perusahaan berpengaruh terhadap kinerja perusahaan.

Berdasarkan kesimpulanyang terdapat dalam penelitian ini, maka peneliti menyarankan dalam upaya perbaikan penulisan untuk penelitian selanjutnya antara lain:

1. Penelitianselanjutnyadiharapkandapatme nambahjumlahsampelperusahaandarisem uasektor agar dapatmewakilipopulasiuntukmengetahuip engaruh CSR utamanyaterhadapkinerjaperusahaan.

2. Penelitianselanjutnyadiharapkandapatme nggunakan item pengukur yang lebihbanyakdan detail, misalnyadenganmengadopsi GRI (Global Reporting Initiative) versi 4 (2013) agar hasillebihakuratdanrelevan.

3. Penelitianselanjutnyadiharapkandapatme nambahkanataumenggunakanvariabellain untukmenemukansuatu model standarpengaruhkinerjaperusahaan. Misalnyamenggunakanstrukturpengendal ianeksternalperusahaansepertipasar modal, pasaruang, regulator danprofesilainnya (paralegal, auditor dan lain sebagainya). 


\section{DAFTAR PUSTAKA}

\section{$\underline{10.22202 / e c o n o m i c a .2016 . v 4 . i 2.380}$}

Bukhori, I. (2012). Pengaruh Corporate Governance Dan Ukuran Perusahaan Terhadap Kinerja Perusahaan (Studi Empiris pada Perusahaan yang Terdaftar di BEI 2010. Diponegoro Journal Of Accounting .

Ghozali, I. (2006). Aplikasi Analisis Multivariat dengan Program SPSS. Semarang: Universitas Diponegoro.

Hana, Z. R. (2013). Pengaruh Pengungkapan Corporate Social Responsibility Terhadap Kinerja Keuangan Perusahaan Telekomunikasi yang Terdaftar Di Bursa Efek Indonesia. Malang: Universitas Brawijaya.

Hardikasari, E. (2011). Pengaruh Penerapan Corporate Governance Terhadap Kinerja KeuangaPada Industri Perbankan Yang Terdaftar Di Bursa Efek Indonesia (BEI) Tahun 20062008. Dalam Undergraduate thesis. Semarang: Universitas Diponegoro.

Khafa, L. (2015). Pengaruh CSR, Ukuran Perusahaan, Leverage, dan Keputusan Investasi Pada Kinerja Keuangan Perusahaan dan Nilai Perusahaan (Studi Empiris pada Perusahaan Manufaktur yang terdaftar di Bursa Efek Indonesia tahun 2012-2013). Dalam Undergraduate thesis. Semarang: Universitas Diponegoro.

Mulyadi, D. (2014). Analisis Pengaruh Good Corporate Governance Dan Leverage Terhadap Kinerja Keuangan Perusahaan Otomotif Di Bursa Efek Indonesia Tahun 2009-2012. Dalam Undergraduate thesis. Surakarta:
Universitas

Muhammadiyah

Surakarta.

Muntiah, S. (2014). Pengaruh Mekanisme Corporate Governance Terhadap Kinerja Perusahaan. Dalam Dokumen Karya Ilmiah. Semarang: Fakultas Ekonomi Bisnis Universitas Dian Nuswantoro.

Peruno, D. D. (2015). Pengaruh Mekanisme Good Corporate Governance Terhadap Kinerja Perusahaan Perbankan Yang Terdaftar Di Bursa Efek Indonesia Tahun 2009-2011. Dalam Undergraduate thesis. Yogyakarta: Universitas Negeri Yogyakarta.

Rifan, D. F., Andi, K., \& Widiyanti, A. (2015). Pengaruh Pengungkapan Corporate Social Responsibility dan Ukuran Perusahaan Terhadap Kinerja Keuangan (Studi pda Perusahaan Pertambangan yang Listing di BEI Tahun 2010-2013). Lampung: Fakultas Ekonomi dan Bisnis Universitas Lampung.

Sembiring, E. R. (2005). Karakteristik Perusahaan dan Pengungkapan Tanggung Jawab Sosial: Studi Empiris pada Perusahaan yang Tercatat di Bursa Efek Jakarta. Simposium Nasional Akuntansi .

Setiyowati, S. W., \& Sari, A. R. (2015). Pengaruh Pengungkapan Corporate Social Responsibilty Terhadap Kinerja Keuangan Perusahaan Manufaktur Dan Pertambangan Di Bursa Efek Indonesia Dengan Corporate Governance Sebagai Variabel Moderasi. Asia Pacific Conference on Accounting and Finance. 
Siagian, T. P. (2013). Analisis Pengaruh Corporate Governance Terhadap Kinerja Perusahaan (Studi Empiris pada Perusahaan Perdagangan dan Jasa). Diponegoro Journal of Accounting .

Sukandar, P. P. (2014). Pengaruh Ukuran Dewan Direksi Dan Dewan Komisaris Serta Ukuran Perusahaan Terhadap Kinerja Keuangan Perusahaan (Studi Empiris Pada Perusahaan Manufaktur Sektor
Consumer Good yang Terdaftar di BEI Tahun 2010 - 2012). Dalam Undergraduate thesis. Semarang: Universitas Diponegoro.

www.idx.co.id

Yudha, E. P., Latifah, S. W., \& Prasetyo, A. (2015). Pengaruh Corporate Governance Terhadap Kinerja Keuangan Perusahaan Manufaktur yang Go Public Di BEI. KRA II .

\section{Lampiran}

Tabel 1

KeputusanUjiDurbin-Watson

\begin{tabular}{lcc}
\hline \multicolumn{1}{c}{ Hipotesis 0} & Keputusan & Jika \\
\hline $\begin{array}{l}\text { Tidak ada autokorelasi positif } \\
\text { atau negatif }\end{array}$ & Tidakditolak & $\mathrm{du}<\mathrm{d}<4-\mathrm{du}$ \\
Tidak ada autokorelasi positif & Tolak & $0<\mathrm{d}<\mathrm{dl}$ \\
Tidak ada autokorelasi positif. & No decision & $\mathrm{dl} \leq \mathrm{d} \leq \mathrm{du}$ \\
Tidak ada korelasi negatif & Tolak & $4-\mathrm{dl}<\mathrm{d}<4$ \\
Tidak ada korelasi negatif & No decision & $4-\mathrm{du} \leq \mathrm{d} \leq 4-\mathrm{dl}$ \\
\hline
\end{tabular}

Tabel 2

Pemilihan Sampel

Ketarangan Jumlah

- Perusahaan manufaktur sektor indutri dasar dan kimia

64 yang listing di BEI tahun 2012-2014.

- Tidak memenuhi kriteria sampling 
Tabel 3

Deskripsi Variabel Penelitian

Descriptive Statistics

\begin{tabular}{lrrrrr}
\hline & $N$ & & Minimum & Maximum & \multicolumn{2}{c}{ Mean } & Std. Deviation \\
Dewan Direksi & 63 & 2.00 & 11.00 & 5.5873 & 2.57554 \\
\hline Dewan Komisaris & 63 & 2.00 & 9.00 & 4.4603 & 1.73042 \\
Ukuran Perusahaan & 63 & 11.11 & 13.54 & 12.2757 & .70995 \\
CSR & 63 & .09 & .76 & .3382 & .18713 \\
Kinerja Perusahaan & 63 & .00 & .35 & .1023 & .08766 \\
Valid N (listwise) & 63 & & & & \\
\hline
\end{tabular}

Tabel 4

Hasil Uji Normalitas

One-Sample Kolmogorov-Smirnov Test

\begin{tabular}{llr}
\hline $\mathrm{N}$ & Mean & $\begin{array}{r}\text { Unstandardized } \\
\text { Residual }\end{array}$ \\
Normal Parameters & \\
& Std. Deviation & .0000000 \\
Most Extreme Differences & Absolute & .07541539 \\
& Positive & .095 \\
& Negative & .095 \\
Kolmogorov-Smirnov Z & &. .053 \\
Asymp. Sig. (2-tailed) & & .755 \\
a. Test distribution is Normal. & .618 \\
\hline
\end{tabular}

Tabel 5

Coefficients $^{a}$

\begin{tabular}{|c|c|c|c|c|c|c|c|c|}
\hline & & \multicolumn{2}{|c|}{$\begin{array}{l}\text { Unstandardized } \\
\text { Coefficients }\end{array}$} & \multirow{2}{*}{$\begin{array}{c}\begin{array}{c}\text { Standardized } \\
\text { Coefficients }\end{array} \\
\text { Beta }\end{array}$} & \multirow[b]{2}{*}{$\mathrm{t}$} & \multirow[b]{2}{*}{ Sig. } & \multicolumn{2}{|c|}{$\begin{array}{l}\text { Collinearity } \\
\text { Statistics }\end{array}$} \\
\hline \multicolumn{2}{|c|}{ Model } & $\mathrm{B}$ & Std. Error & & & & Tolerance & VIF \\
\hline \multirow[t]{5}{*}{1} & (Constant) & -.518 & .180 & & -2.883 & .006 & & \\
\hline & Dewan Direksi & .002 & .005 & .061 & .396 & .694 & .537 & 1.863 \\
\hline & Dewan Komisaris & -.002 & .007 & -.037 & -.253 & .801 & .606 & 1.650 \\
\hline & CSR & .076 & .075 & .164 & 1.013 & .315 & .485 & 2.063 \\
\hline & Ukuran Perusahaan & .048 & .015 & .399 & 3.113 & .003 & .778 & 1.286 \\
\hline
\end{tabular}

a. Dependent Variable: Kinerja Perusahaan 


\section{Scatterplot}

\section{Dependent Variable: Kinerja Perusahaan}

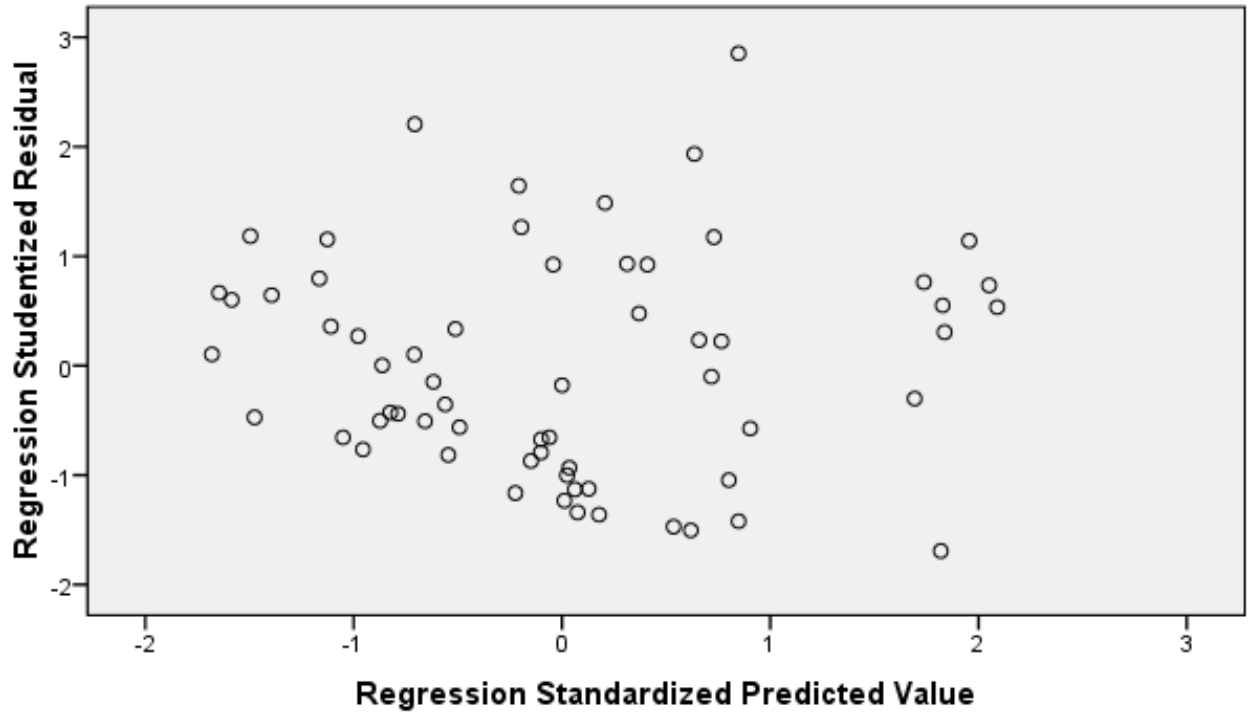

Tabel 6

Model Summary

\begin{tabular}{|c|c|c|c|c|c|}
\hline Model & $\mathrm{R}$ & R Square & $\begin{array}{l}\text { Adjusted R } \\
\text { Square }\end{array}$ & $\begin{array}{l}\text { Std. Error of the } \\
\text { Estimate }\end{array}$ & Durbin-Watson \\
\hline 1 & $.510^{\mathrm{a}}$ & .260 & .209 & .077973 & 2.206 \\
\hline
\end{tabular}

a. Predictors: (Constant), Ukuran Perusahaan, Dewan Komisaris, Dewan Direksi, CSR

b. Dependent Variable: Kinerja Perusahaan

Tabel 7

ANOVA $^{b}$

\begin{tabular}{|c|c|c|c|c|c|c|}
\hline Model & & $\begin{array}{l}\text { Sum of } \\
\text { Squares }\end{array}$ & df & Mean Square & $\mathrm{F}$ & Sig. \\
\hline \multirow[t]{3}{*}{1} & Regression & .124 & 4 & .031 & 5.093 & $.001^{\mathrm{a}}$ \\
\hline & Residual & .353 & 58 & .006 & & \\
\hline & Total & .476 & 62 & & & \\
\hline
\end{tabular}

a. Predictors: (Constant), Ukuran Perusahaan, Dewan Komisaris, Dewan Direksi, CSR 
ANOVA $^{b}$

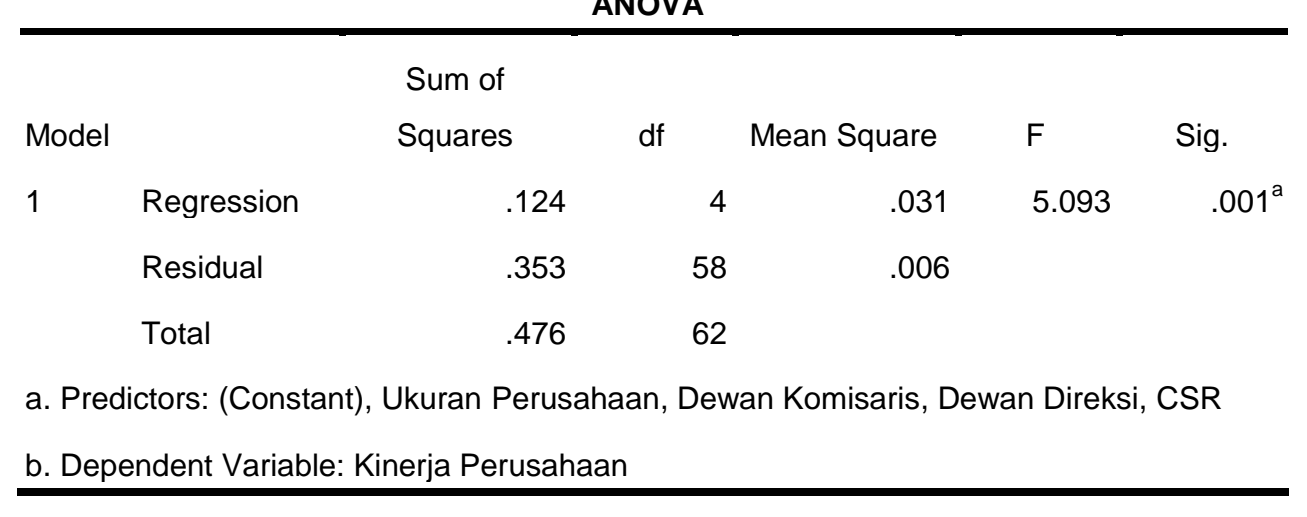

